\title{
Effects of nitrogen deposition rates and frequencies on the abundance of soil nitrogen-related functional genes in temperate grassland of northern China
}

\author{
Qiushi Ning • Qian Gu • Jupei Shen • Xiaotao Lv • \\ Junjie Yang • Ximei Zhang • Jizheng He • Jianhui Huang • \\ Hong Wang • Zhihong Xu • Xingguo Han
}

Received: 7 July 2014 / Accepted: 6 January 2015 / Published online: 16 January 2015

(C) Springer-Verlag Berlin Heidelberg 2015

\begin{abstract}
Purpose Microbial processes driving nitrogen (N) cycling are hot topics in terms of increasing $\mathrm{N}$ deposition. Abundances of $\mathrm{N}$-related functional genes (NFG) can be most responsive to $\mathrm{N}$ deposition and commonly used to represent $\mathrm{N}$ transformation rates. However, empirically simulated $\mathrm{N}$ deposition has been exclusively conducted through large and infrequent $\mathrm{N}$ fertilization, which may have caused contrasting effects on NFGs.
\end{abstract}

Responsible editor: Yanfen Wang

Q. Ning $\cdot$ Q. Gu $\cdot$ J. Huang $\cdot$ X. Han

State Key Laboratory of Vegetation and Environmental Change, Institute of Botany, Chinese Academy of Sciences, Beijing 100093, People's Republic of China

Q. Ning • Q. Gu

University of Chinese Academy of Sciences, Beijing 100049,

People's Republic of China

X. Lv $\cdot$ J. Yang $\cdot X$. Zhang $\cdot X$. Han $(\bowtie)$

State Key Laboratory of Forest and Soil Ecology, Institute of Applied Ecology, Chinese Academy of Sciences, Shenyang 110164, People's Republic of China

e-mail:xghan@ibcas.ac.cn

H. Wang

Semiarid Prairie Agricultural Research Centre, Agriculture and Agri-Food Canada, Swift Current, Saskatchewan S9H 3X2, 1030, Canada

J. Shen $\cdot$ J. He

State Key Laboratory of Urban and Regional Ecology, Research Centre for Eco-environmental Sciences, Chinese Academy of

Sciences, Beijing 100085, People's Republic of China

Q. Ning $\cdot$ J. He $\cdot$ Z. Xu $(\bowtie)$

Environmental Futures Research Institute, Griffith University,

Nathan QLD 4111, Australia

e-mail: zhihong.xu@griffith.edu.au
Therefore, experiments with small and frequent $\mathrm{N}$ additions closed to natural deposition are necessary.

Materials and methods Independently manipulated $\mathrm{N}$ addition rates (i.e., $0,5,10,15,20$, and $50 \mathrm{~g} \mathrm{~N} \mathrm{~m}^{-2}$ year $^{-1}$ ) and two frequencies ( 2 times per year addition as conventional large and infrequent $\mathrm{N}$ fertilization $(2 \mathrm{~N})$, and 12 times per year addition simulating small and frequent $\mathrm{N}$ deposition $(12 \mathrm{~N})$, respectively) were conducted in a long-term field experiment of a semiarid grassland in northern China. Quantification analysis using real-time PCR were carried out for $\mathrm{NFGs}$, including nifH for $\mathrm{N}$ fixation, chiA for $\mathrm{N}$ mineralization, archaeal (AOA) and bacterial (AOB) amo $A$ for nitrification, and narG, nirS, nirK, and nos $Z$ for denitrification.

Results and discussion NFG abundances showed distinct sensitivities to $\mathrm{N}$ addition rates. The nifH, AOA-amoA, nirS, and nos $Z$ gene abundances increased due to improved available $\mathrm{N}$ at low $\mathrm{N}$ rates, but suppressed by salt toxicity and acidification at high $\mathrm{N}$ rates. Large changes of chiA and $\mathrm{AOB}$-amoA gene abundances highlighted their great sensitivities to the $\mathrm{N}$ enrichment. The abundance of AOB-amo $A$ was more sensitive to $\mathrm{N}$ addition than AOA-amoA, but AOA-amoA dominated in absolute numbers and they predominated the ammoniaoxidation under different conditions. The $\mathrm{N}$ addition frequencies caused significant lower gene abundances of nifH, nirS, and nos $Z$ under the 2-N frequency due to stronger suppression of acidification and salt toxicity and resulted in significant higher AOB-amoA gene abundances in response to higher $\mathrm{N}$ availability under the 2-N frequency.

Conclusions The NFGs abundances responded to $\mathrm{N}$ addition rates distinctly, highlighting that the driven processes involved in $\mathrm{N}$ cycling were altered by the $\mathrm{N}$ addition rates. The different effects of two $\mathrm{N}$ addition frequencies on NFG abundances demonstrated that conventional large and infrequent $\mathrm{N}$ fertilization cannot represent $\mathrm{N}$ deposition, and small and frequent 
$\mathrm{N}$ addition should be employed to project the effects of $\mathrm{N}$ deposition on microbial functional groups as well as on $\mathrm{N}$ transformations.

Keywords Functional gene - Nitrogen addition frequency . Nitrogen addition rate $\cdot$ Nitrogen deposition $\cdot$ Nitrogen transformation $\cdot$ Temperate grassland

\section{Introduction}

Nitrogen $(\mathrm{N})$ is considered to be the nutrient most likely to limit production in terrestrial ecosystems (Vitousek and Howarth 1991; Xu and Chen 2006; Xu et al. 2009). The rate of atmospheric $\mathrm{N}$ deposition has rapidly increased due to intensive anthropogenic activities and therefore results in the alteration of ecosystem processes and functions (Galloway et al. 2004, 2013; Sala et al. 2000; Xu and Chen 2006; Xu et al. 2009). There is increasing evidence that $\mathrm{N}$ enrichment can produce wide-ranging impacts on the microbial diversity and biomass (Sala et al. 2000; Treseder 2008) as well as the biogeochemical processes (Ramirez et al. 2012) including N transformation rates (Ochoa-Hueso et al. 2013) and the emissions of greenhouse gases (Treseder 2008). However, infrequent addition of simulated $\mathrm{N}$ deposition with infrequent $\mathrm{N}$ fertilization might cause contrasting evaluation of impacts on $\mathrm{N}$ cycling processes compared with continuous natural $\mathrm{N}$ deposition. It has been proven that the effects of $\mathrm{N}$ addition frequencies differed significantly on ecosystems, such as different available plant $\mathrm{N}$ concentration (Cheng et al. 2009), ammonia emissions (Zhang et al. 2014a), plant species loss (Zhang et al. 2014b), net ecosystem $\mathrm{CO}_{2}$ exchange and radiation-use efficiency (Barton et al. 2008), and plant biomass (Bilbrough and Caldwell 1997). Consequently, experiments with wide range of rates and varying frequencies are imperative to understand the influences of $\mathrm{N}$ deposition on ecosystems (Zhang et al. 2014b), especially on microbial processes involving in $\mathrm{N}$ cycling.

Effects of $\mathrm{N}$ deposition have garnered considerable attention surrounding microorganisms (Stevens et al. 2010). In various ecosystems, microorganisms drive many fundamental $\mathrm{N}$ transformation processes (Hallin et al. 2009; Petersen et al. 2012; Veresoglou et al. 2012), such as $\mathrm{N}$ fixation, $\mathrm{N}$ mineralization, nitrification, and denitrification. $\mathrm{N}$-related functional genes (NFG), such as nifH for $\mathrm{N}$ fixation, chiA for $\mathrm{N}$ mineralization, archaeal (AOA) and bacterial (AOB) amoA for nitrification, and $\operatorname{nar} G$, nirS, nirK, and $\operatorname{nos} Z$ genes for denitrification, encoding the key enzymes responsible for the $\mathrm{N}$ transformation processes and could be used as a proxy for measuring $\mathrm{N}$ transformation rates in soil (Colloff et al. 2008; Lindsay et al. 2010; Petersen et al. 2012; Zhang et al. 2013). N deposition is promoting major alterations of $\mathrm{N}$ cycling processes (Ochoa-Hueso et al. 2013) and NFG abundances (Kandeler et al. 2009) in ecosystems. The form of $\mathrm{N}$ addition to soil and its effect on soil properties play important roles in the microbial community responses to $\mathrm{N}$ additions (LevyBooth et al. 2014). For example, the research carried out by Jung et al. (2011) showed that the addition of $\mathrm{N}$ caused increased nifH gene abundance; Zhang et al. (2013) found decreased chiA gene abundance with $\mathrm{N}$ addition; AOA-amoA gene abundance might be important an factor in low-nutrient environments (Erguder et al. 2009), which was in contrast with AOB-amoA gene abundance (Di et al. 2010; Jia and Conrad 2009); and the size of the total nitrate reducer and denitrifier communities did not respond to the reduced $\mathrm{N}$ deposition (Kandeler et al. 2009). However, previous intensive research thus far investigates one single step, such as the initial nitrification step ammonia-oxidation (Leininger et al. 2006) or denitrification with loss of gaseous products (Attard et al. 2011; Kandeler et al. 2006), and the fact that $\mathrm{N}$ transformation is a network of closely interlinked processes and has been commonly neglected (Hai et al. 2009; Shen et al. 2014; Wang et al. 2014). Consequently, experiment of NFG quantification corresponding to all key steps should be conducted to better understand $\mathrm{N}$ transformation (Shen et al. 2014).

Therefore, we sought to investigate the effect of $\mathrm{N}$ deposition rates and frequencies on key $\mathrm{N}$ transformation processes including $\mathrm{N}$ fixation, $\mathrm{N}$ mineralization, nitrification, and denitrification. We hypothesized that different $\mathrm{N}$ frequencies induced different responsive patterns of NFG abundances, and further postulated that NFG abundances and corresponding N transformation processes were also influenced by different edaphic conditions resulting from $\mathrm{N}$ addition rates and frequencies. To test these hypotheses, we conducted a $\mathrm{N}$ deposition experiment in 2011, with independently manipulated $\mathrm{N}$ addition frequencies $(2 \mathrm{~N}$ and $12 \mathrm{~N})$ and rates $(0,5,10,15,20$, and $50 \mathrm{~g} \mathrm{~N} \mathrm{~m}^{-2}$ year $^{-1}$ ), with quantifying NFG abundance, on a molecular basis through a real-time PCR method and linking the data to edaphic properties. This allowed us to detect the responses of NFGs to distinct $\mathrm{N}$ addition rates and frequencies, and to explore the possible underlying mechanisms.

\section{Materials and methods}

\subsection{Experimental site}

This study was carried out in a semiarid grassland ecosystem near the Inner Mongolia Grassland Ecosystem Research Station (IMGRES) of the Chinese Academy of Sciences ( $43^{\circ} 13^{\prime}$ $\mathrm{N}, 116^{\circ} 14^{\prime} \mathrm{E} ; 1250-1260$ m.a.s.l). The experimental site had been fenced since 1999 to exclude large animal grazing. The average annual temperature is $0.9^{\circ} \mathrm{C}$ and mean monthly temperature ranges from $-21.4{ }^{\circ} \mathrm{C}$ in January to $19.7{ }^{\circ} \mathrm{C}$ in July. 
Mean annual precipitation is $355.3 \mathrm{~mm}$, with $60-80 \%$ mainly occurring from May to August. The soil is classified as Haplic Calcisol and Calcic-orthic Aridisol by the FAO and US Soil Taxonomy classification system, respectively (Zhang et al. $2014 b$ ). The mean annual $\mathrm{N}$ deposition was less than $1.5 \mathrm{~g} \mathrm{~N} \mathrm{~m}^{-2}$ year $^{-1}$ in this experimental area for the immediate past 20 years' period (Jia et al. 2014), and no fertilizer had been applied prior to the experiment (Zhang et al. 2014b). The $\mathrm{N}$ is limiting in the experiment field as Bai et al. (2010) found that the $\mathrm{N}$ saturate rate is approxiamately $10.5 \mathrm{~g} \mathrm{~N} \mathrm{~m}^{-2}$ year $^{-1}$ at IMGERS. The vegetation is dominated by Leymus chinensis, Stipa grandis, Cleistogenes squarrosa, Agropyron cristatum, and Achnatherum sibiricum. The main dominant $\mathrm{N}$-fixing bacteria are free-living diazotrophs as no legumes were present at this experimental site.

\subsection{Experimental design}

The experimental N deposition started in September 2008 and was laid out in a completely randomized block design as described in detail (Zhang et al. 2014b). Briefly, nine $\mathrm{N}$ addition rates $\left(0,1,2,3,5,10,15,20\right.$, and $50 \mathrm{~g} \mathrm{~N} \mathrm{~m}^{-2}$ year $\left.^{-1}\right)$ with two $\mathrm{N}$ addition frequencies: 2 and $12 \mathrm{~N}$ additions per year were involved. In this study, we randomly selected $5 \mathrm{~N}$ addition rates $\left(5,10,15,20\right.$, and $50 \mathrm{~g} \mathrm{~N} \mathrm{~m}^{-2}$ year $\left.^{-1}\right)$ with two $\mathrm{N}$ addition frequencies and control treatment $(\mathrm{N}$ addition rate $0 \mathrm{~g} \mathrm{~N} \mathrm{~m}^{-2}$ year $^{-1}$ ) in three blocks, in brief, 33 plots were analyzed. Each replicate was designed as a block separated by 2-m buffer; the plot was randomly located within the block $(45 \mathrm{~m} \times 70 \mathrm{~m})$ and separated by $1-\mathrm{m}$ buffer; size of each plot was $8 \mathrm{~m} \times 8 \mathrm{~m}$.

We constructed purified ammonium nitrate $\left(\mathrm{NH}_{4} \mathrm{NO}_{3}\right)$ supplied as $\mathrm{N}$ resource. Firstly, experimental $\mathrm{N}$ deposition started on 1st September 2008 for the high frequency (12 N additions per year) and 1st November 2008 for the low frequency ( $2 \mathrm{~N}$ additions per year), and then the $\mathrm{N}$ addition continued on $1 \mathrm{st}$ day of every month for the high frequency and on the 1st of June and November for the low frequency. When the monthly $\mathrm{N}$ was added in August of each year, total annual loading $\mathrm{N}$ was equal between the 2-N and 12-N addition frequencies. The $\mathrm{NH}_{4} \mathrm{NO}_{3}$ was dissolved in distilled water and evenly sprayed to the plot $(9.0 \mathrm{~L}$ for the $2 \mathrm{~N}$ in June and $1.5 \mathrm{~L}$ for the $12 \mathrm{~N}$ each month) during the growing season from May to October; from November to the next April, $\mathrm{NH}_{4} \mathrm{NO}_{3}$ was blended with washed fine sand and evenly applied by hand in November for the $2 \mathrm{~N}$ and on the 1st day of winter months from November to April for the $12 \mathrm{~N}$.

\subsection{Sampling}

For each plot, we took six soil cores $(3 \mathrm{~cm}$ in diameter) from surface to $10-\mathrm{cm}$ depth at random and blended them as a composite sample after sieving through a 1-mm mesh in August 2011. The composite sample was divided into four subsamples: one was stored at $-80{ }^{\circ} \mathrm{C}$ for nucleic acid extraction; the second was to determine soil water content after $24 \mathrm{~h}$ drying at $105^{\circ} \mathrm{C}$; the third was airdried for measuring soil $\mathrm{pH}$ and total $\mathrm{C}, \mathrm{N}$, and $\mathrm{P}$; and the fourth was used to measure ammonium and nitrate within $24 \mathrm{~h}$ after sampling.

\subsection{Soil physical and chemical properties}

Soil moisture was determined using the gravimetric method and soil $\mathrm{pH}$ (water/soil=2.5:1) was measured with a SevenEasy pH Meter (Mettler-Toledo; USA). Air-dried soil was ground with a ball mill (Retsch MM 400, Retsch GmbH \& Co KG, Haan, Germany). Soil total $\mathrm{C}$ concentration was determined using $\mathrm{H}_{2} \mathrm{SO}_{4}-\mathrm{K}_{2} \mathrm{Cr}_{2} \mathrm{O}_{7}$ oxidation method (Nelson and Sommers 1982). Total $\mathrm{N}$ concentration was determined using the Kjeldahl acid-digestion method with an Alpkem autoanalyzer (Kjektec System 1026 Distill Unit, Sweden). Total $P$ concentration was determined colorimetrically at $880 \mathrm{~nm}$ after reaction with molybdenum blue. Inorganic $\mathrm{N}$ was extracted with $2 \mathrm{M} \mathrm{KCl}$; extractable $\mathrm{NH}_{4}{ }^{+}-\mathrm{N}$ and $\mathrm{NO}_{3}{ }^{-}-\mathrm{N}$ were analyzed colorimetrically using a continuous flow injection analyzer (FIAStar, Foss Tecator, Höganäs, Sweden).

\subsection{Nucleic acid extraction}

DNA was extracted from $0.5 \mathrm{~g}$ soil using the FastDNA ${ }^{\circledR}$ SPIN Kit (MP Biomedicals, Irvine, CA). Yield and purity of the extracted DNA were checked with a spectrophotometer (Nanodrop, PeqLab, Germany); the $350 \mu \mathrm{L}$ DNA elution solution was used to elute extracted DNA in the tenth step. Afterwards, extracts were stored at $-20{ }^{\circ} \mathrm{C}$ until use.

\subsection{Real-time PCR assays}

Absolute quantification of all investigated genes was conducted on a ABI7500Fast Real-Time PCR System (Applied Biosystems, Germany) using SybrGreen as fluorescent dye. Quantitative real-time PCR was performed in 96-well plates for all eight target genes. To create a standard curve, plasmid DNA containing each target gene was serially diluted from $10^{1}$ to $10^{6}$ gene copies per microliter. All samples, standard series, and negative controls were run in triplicate. The $25-\mu \mathrm{L}$ PCR amplification mixtures containing $12.5 \mu \mathrm{L}$ SybrGreen qPCR Master Mix $(\times 2)$ (Shanghai Ruian BirTechnologies Co., Ltd., Shanghai, China), $0.5 \mu \mathrm{L}$ each primer $(20 \mu \mathrm{M})$, $10 \mu \mathrm{L}$ sterile and DNA-free water, and $1.5 \mu \mathrm{L}$ standard plasmid. The bovine serum albumin (BSA) was included in the SybrGreen qPCR Master Mix to provide some resistance to inhibitors such as co-extracted polyphenolic compounds of the soil. The primers nifHF and nifHR for nifH gene (Rösch et al. 2002), chif2 and chir for chiA gene (Xiao et al. 2005), 
Arch-amoAF and Arch-amoAR for AOA-amo $A$ gene (Francis et al. 2005), AmoA-1F and AmoA-2R for AOB-amoA gene (Rotthauwe et al. 1997), narGf and narGr for narG gene (Delorme et al. 2003), cd3aF and R3cd for nirS gene (Michotey et al. 2000; Throbäck et al. 2004), nirk-1F and nirk-5R for nirK gene (Braker et al. 1998), and nosZ-F and nosZ-R for nos $Z$ gene (Kloos et al. 2001) were used. The specificity of the amplification products was confirmed by melting-curve analysis, and the sizes of the amplified fragments were checked in a $2 \%$ agarose gel. The thermal profile for genes of nifH, chiA, AOA-amo A, AOB-amo $A$, and nirK was as follow: $95^{\circ} \mathrm{C}$ for $2 \mathrm{~min}$ and 40 cycles of $95^{\circ} \mathrm{C}$ for $10 \mathrm{~s}, 55^{\circ} \mathrm{C}$ for $10 \mathrm{~s}$, and $72{ }^{\circ} \mathrm{C}$ for $1 \mathrm{~min}$. The thermal profile for genes of narG, nirS, and $n o s Z$ was as follow: $95{ }^{\circ} \mathrm{C}$ for $2 \mathrm{~min}$ and 40 cycles of $95^{\circ} \mathrm{C}$ for $10 \mathrm{~s}$, and $60^{\circ} \mathrm{C}$ for $1 \mathrm{~min}$. The formula $\mathrm{Eff}=\left[10^{(-1 /}\right.$ slope) - 1] was used to calculate the amplification efficiencies. Preceding tests with dilution series of the extracted DNA showed that the inhibitory effect was negligible.

\subsection{Statistical analyses}

Data normality distribution was checked by KolmogorovSmirnov test. One-way analysis of variance (ANOVA) was used to test the variance of gene abundances and soil physicochemical properties in all plots. Two-way ANOVAs were used to test the interactive effect of $\mathrm{N}$ addition rates and frequencies on gene abundances and soil physiochemical properties. Gene abundances were determined by polynomial quadratic and linear regressions with $\mathrm{N}$ addition rates and physicochemical properties, and the best-fitting regression models were adopted and presented, statistical significance was set at $p<0.05$. Multiple regressions of NFG abundances with soil properties and $\mathrm{N}$ addition rates and frequencies were checked, statistical significance was set at $p<0.1$. All statistical analyses were performed using statistical software SAS V8 (SAS institute, USA) and Statistix 8.0 (Analytical Software, USA); all figures were created by graphing software SigmaPlot 11 (Systat software Inc, USA).

\section{Results}

\subsection{Soil physical and chemical properties}

Soil $\mathrm{pH}$ values in response to the two $\mathrm{N}$ addition frequencies revealed a statistically significant difference $(p<0.001)$ (Fig. 1a, b), with $\mathrm{N}$ addition leading to more acidic conditions under the $2-\mathrm{N}$ frequency. Soil $\mathrm{pH}$ with both frequencies negatively correlated with $\mathrm{N}$ addition rates. It was noteworthy that soil $\mathrm{pH}$ exerted a sharp plunge from 20 to $50 \mathrm{~g} \mathrm{~N} \mathrm{~m}^{-2}$ year $^{-1}$, especially for the 2-N frequency. Higher $\mathrm{NH}_{4}{ }^{+}-\mathrm{N}$ concentrations $(p<0.001)$
(Fig. 1c, d) and $\mathrm{NO}_{3}{ }^{-}-\mathrm{N}$ concentrations $(p<0.001)$ were detected under the 2-N frequency (Fig. 1e, f). Both $\mathrm{NH}_{4}{ }^{+}-$ $\mathrm{N}$ and $\mathrm{NO}_{3}{ }^{-}-\mathrm{N}$ concentrations increased with the $\mathrm{N}$ addition rates for the two $\mathrm{N}$ addition frequencies.

There were no differences in soil total $\mathrm{C}, \mathrm{N}$, and $\mathrm{P}$ concentrations and their ratios between the two $\mathrm{N}$ addition frequencies. Total $\mathrm{N}$ concentration significantly positively correlated with $\mathrm{N}$ addition rates $\left(R^{2}=0.41, p=\right.$ $0.005,2 \mathrm{~N} ; R^{2}=0.28, p=0.025,12 \mathrm{~N}$; Fig. $\left.2 \mathrm{~b}\right)$. Negative correlations were found between $\mathrm{C} / \mathrm{N}$ ratios and $\mathrm{N}$ addition rates $\left(R^{2}=0.46, p=0.002,2 \mathrm{~N} ; \mathrm{R}^{2}=0.37, p=0.008\right.$, $12 \mathrm{~N}$; Fig. 2d). The $\mathrm{C} / \mathrm{P}$ ratios in the $12 \mathrm{~N}$ plots negatively $\left(R^{2}=0.26, p=0.029\right.$; Fig. $\left.2 \mathrm{e}\right)$ and $\mathrm{N} / \mathrm{P}$ ratios in $2 \mathrm{~N}$ plots positively correlated with $\mathrm{N}$ addition rates $\left(R^{2}=\right.$ $0.40, p=0.005$; Fig. 2f), respectively.

\subsection{Abundance of $\mathrm{N}$ functional genes}

Except for narG gene, all the other NFGs were responsive to the $\mathrm{N}$ addition, and significant differences between the two $\mathrm{N}$ addition frequencies were detected in the abundances of nifH, AOB-amoA, nirS, and nosZ genes. For nifH, AOA-amoA, nirK, nir $S$, and nos $Z$, gene abundances first peaked then decreased. The $\mathrm{N}$ rate at 20 and $50 \mathrm{~g} \mathrm{~N} \mathrm{~m}^{-2}$ year ${ }^{-1}$ changed NFG abundances more largely than the other rates in both frequencies. Polynomial quadratic regression model showed nifH $(2 \mathrm{~N}), \operatorname{chi} A(12 \mathrm{~N})$, AOA-amoA $(2 \mathrm{~N}$ and $12 \mathrm{~N})$, AOB-amoA $(2 \mathrm{~N}$ and $12 \mathrm{~N}), \operatorname{nirK}(2 \mathrm{~N}$ and $12 \mathrm{~N}), \operatorname{nirS}(12 \mathrm{~N})$, and $\operatorname{nos} Z$ $(12 \mathrm{~N})$ abundances had hump-shaped relationships with the $\mathrm{N}$ addition rates (see Fig. 3).

\subsubsection{Abundances of nifH gene}

The nifH gene abundance evidently increased in the $2 \mathrm{~N}$ (15 $\mathrm{g} \mathrm{N} \mathrm{m}^{-2}$ year $^{-1}$ ) plots and $12 \mathrm{~N}$ (5, 10 and $15 \mathrm{~g} \mathrm{~N} \mathrm{~m}^{-2}$ year $^{-1}$ ) plots (Fig. 3a), and the abundance was significantly higher under the $12-\mathrm{N}$ frequency than that under the 2-N frequency $(p=0.040)$. The nifH gene abundance negatively correlated with $\mathrm{P}$ concentrations $(r=-0.632, p=$ $0.007)$, and positively correlated with $\mathrm{N} / \mathrm{P}$ ratios $(r=0.499$, $p=0.041$ ) under the $12-\mathrm{N}$ frequency.

\subsubsection{Abundance of chiA gene}

The $\mathrm{N}$ addition reduced the chiA gene abundances in almost all rates of both frequencies excluding non-significant decreases in the $10(p=0.075)$ and $20(p=0.075)$ $\mathrm{g} \mathrm{N} \mathrm{m}^{-2}$ year $^{-1}$ plots under $2 \mathrm{~N}$ frequency (Fig. 3b). Different $\mathrm{N}$ addition frequencies did not produce significant effects on chiA gene abundance $(p=0.871)$. 
Fig. 1 Soil $\mathrm{pH}$, ammonium $\left(\mathrm{NH}_{4}{ }^{+}-\mathrm{N}\right)$, and nitrate $\left(\mathrm{NO}_{3}{ }^{-}-\mathrm{N}\right)$ concentration of $2 \mathrm{~N}$ ( $\mathrm{N}$ addition 2 times/year) and $12 \mathrm{~N}(\mathrm{~N}$ addition 12 times/year) frequencies for control and $\mathrm{N}$ addition rates in August, 2011. Data are mean \pm S.E. Bars with the same letter are not significantly different in Duncan's multiple range tests reported from one-way ANOVA. Regression parameters were calculated using log-linear models with $\mathrm{N}$ rates as a continuous predictor, i.e., $\mathrm{pH}=$ intercept + slope $\times \ln (\mathrm{N})$. Significant regressions are reported as $* p<0.05 ; * * p<0.01$, $* * * p<0.001$

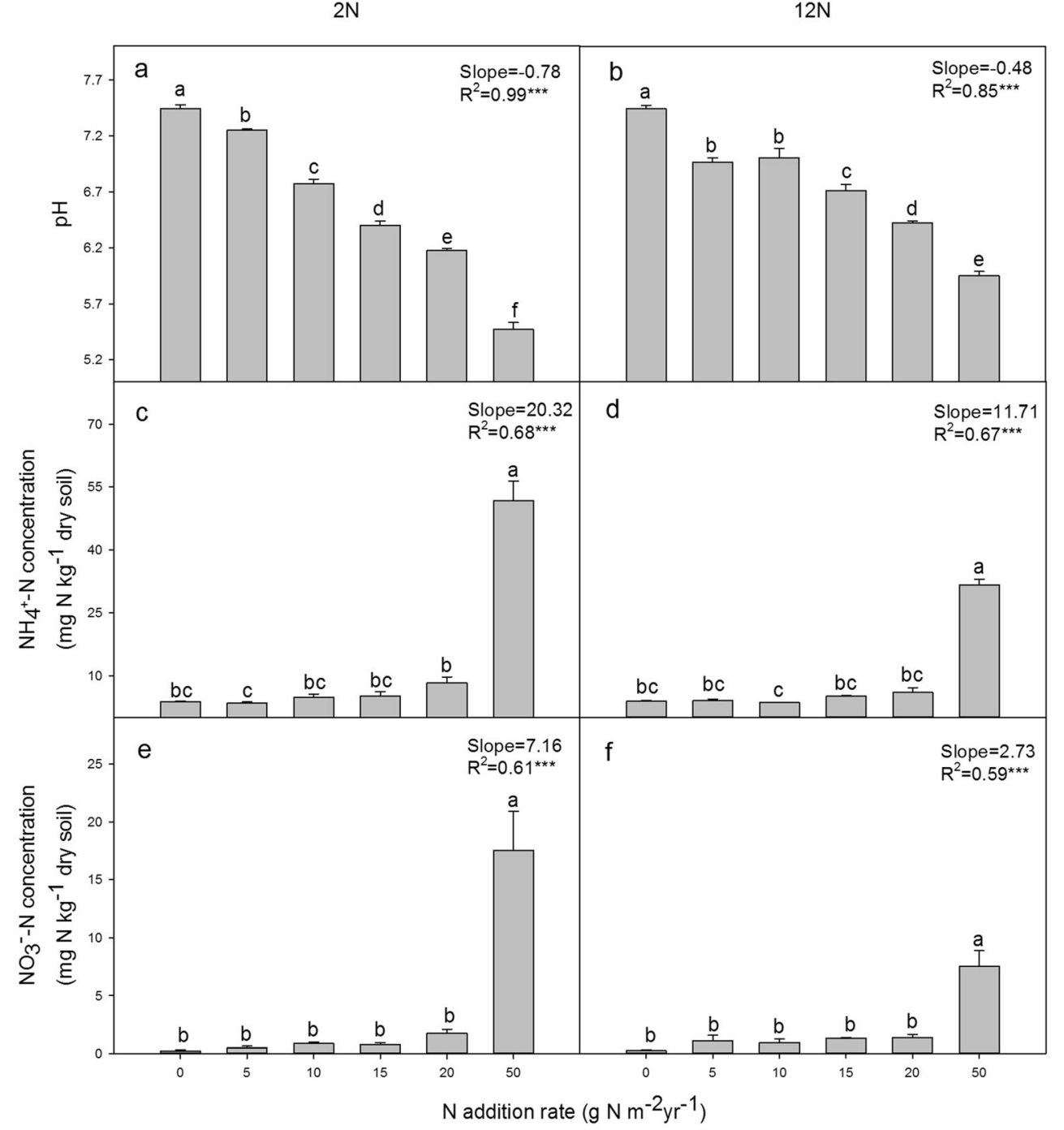

\subsubsection{Abundances of $A O A$-amoA and $A O B$-amoA genes}

AOA-amo $A$ gene abundances showed no significant difference between the two $\mathrm{N}$ addition frequencies (Fig. 3c); AOB-amoA gene abundances under the $2-\mathrm{N}$ frequency were significantly higher than those under the $12-\mathrm{N}$ frequency ( $p=$ 0.030 , Fig. 3d). AOA-amoA abundance peaked in the $15 \mathrm{~g} \mathrm{~N} \mathrm{~m}^{-2}$ year $^{-1}$ plots of the $12 \mathrm{~N}$. Strikingly, in both frequencies, AOB-amoA abundances showed substantial increases across the $\mathrm{N}$ addition rates. Independent of the $\mathrm{N}$ addition rates and frequencies, AOA-amoA gene abundances were clearly dominant over AOB-amoA abundances. Across the $\mathrm{N}$ addition rates, the ratio of $\mathrm{AOA} / \mathrm{AOB}$ gene abundances ranged from 324 in the control plots to 6.04 under the $2 \mathrm{~N}$ and 7.85 under the $12-\mathrm{N}$ frequency, respectively. AOA-amoA gene abundances had quadratic correlations with $\mathrm{NH}_{4}{ }^{+}-\mathrm{N}$ concentrations $\left(R^{2}=0.43, p=0.008,12 \mathrm{~N}\right.$; Fig. $\left.4 \mathrm{a}\right)$ and $\mathrm{NO}_{3}{ }^{-}$$\mathrm{N}$ concentrations $\left(R^{2}=0.32, p=0.026,12 \mathrm{~N}\right.$; Fig. 4b). AOB- amo $A$ gene abundances were found to have strong negative correlations with $\mathrm{pH}(R=-0.816, p<0.001,2 \mathrm{~N} ; R=-0.890$, $p<0.001,12 \mathrm{~N}$ ) and strong correlations with $\mathrm{NH}_{4}-\mathrm{N}$ concentrations (linear, $R^{2}=0.74, p<0.001,2 \mathrm{~N}$; linear, $R^{2}=0.53$, $p<0.001,12 \mathrm{~N}$; Fig. 4c) and $\mathrm{NO}_{3}-\mathrm{N}$ concentrations (linear, $R^{2}=0.70, p<0.001,2 \mathrm{~N}$; quadratic, $R^{2}=0.63, p<0.001,12 \mathrm{~N}$; Fig. $4 d$ ). In the 2-N frequency, AOA-amoA gene abundances positively correlated with soil $\mathrm{P}$ concentration, and AOBamoA gene abundances also positively correlated with soil $\mathrm{N}$ concentrations and negatively correlated with soil $\mathrm{C} / \mathrm{N}$ ratios and $\mathrm{C} / \mathrm{P}$ ratios.

\subsubsection{Abundances of narG, nirK, nirS, and nos Z genes}

The $n a r G$ gene abundance was not affected by the $\mathrm{N}$ addition rates and frequencies (Fig. 3e). Abundances of nirK gene (Fig. 3f) were found to be suppressed at $50 \mathrm{~g} \mathrm{~N} \mathrm{~m}^{-2}$ year $^{-1}$ of both $\mathrm{N}$ addition frequencies $(p=0.024,2 \mathrm{~N} ; p=0.011$, 
Fig. 2 Soil C, N, and P ( $\mathrm{N}$ addition 12 times/year) frequencies for control and $\mathrm{N}$ addition rates. Significant linear regression coefficients of the bestfitting models are reported as ${ }^{*} p<0.05 ; p<0.01 * *$; $* * * p<0.001$. NS indicates nonsignificant $(p>0.05)$ concentration and the ratio of $\mathrm{C} / \mathrm{N}, \mathrm{C} / \mathrm{P}$, and N/P of $2 \mathrm{~N}(\mathrm{~N}$ addition 2 times/year) and $12 \mathrm{~N}$

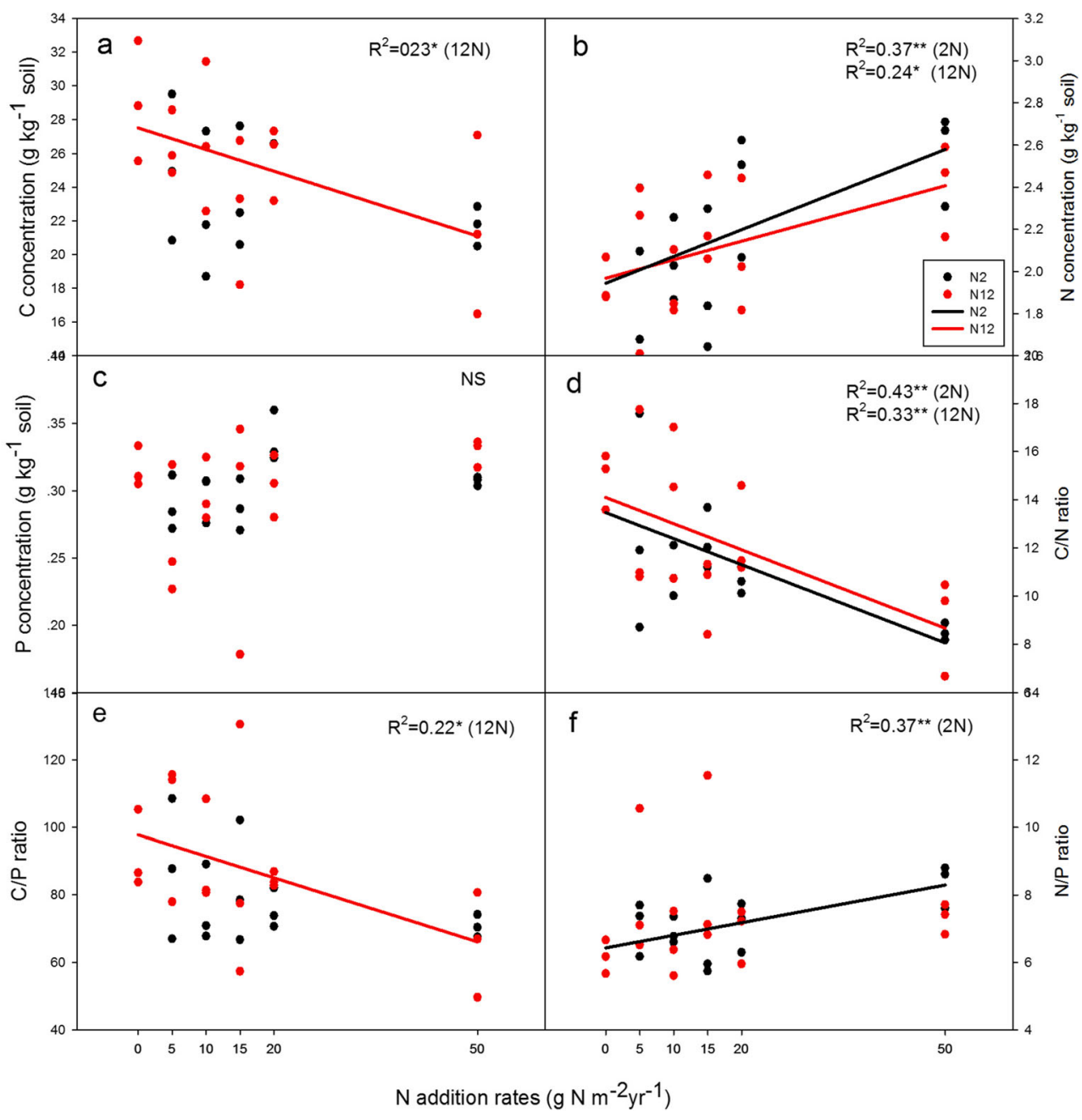

$\mathrm{N}$ concentrations $(R=-0.500, p=0.041)$ under the $12-\mathrm{N}$ frequency.

$12 \mathrm{~N}$ ). The abundance of nirS (Fig. 3g) gene predominated over nirK gene abundance independent of all treatments, even though their functions were the same. The nirK gene abundances were found to have strong quadratic correlations with $\mathrm{NH}_{4}{ }^{+}-\mathrm{N}$ concentrations $\left(R^{2}=0.56, p=0.001,2 \mathrm{~N} ; R^{2}=0.51\right.$, $p=0.003,12 \mathrm{~N}$; Fig. 4e) and $\mathrm{NO}_{3}{ }^{-}-\mathrm{N}$ concentrations $\left(R^{2}=\right.$ $0.47, p=0.005,2 \mathrm{~N} ; R^{2}=0.55, p=0.002,12 \mathrm{~N}$; Fig. 4f), and positive correlation with $\mathrm{pH}(R=0.538, p=0.026,12 \mathrm{~N})$. The nir $S$ gene abundances were significantly enhanced by the $\mathrm{N}$ rates at $5(2 \mathrm{~N}), 10$, and $15(2 \mathrm{~N}$ and $12 \mathrm{~N}) \mathrm{g} \mathrm{N} \mathrm{m}^{-2}$ year $^{-1}$. The $12-\mathrm{N}$ frequencies produced higher gene abundances of nirS ( $p=0.0457)$. Concerning nos $Z$ gene (Fig. $3 \mathrm{~h}$ ), abundances showed increases at the $10(p=0.010), 15(p=0.059)$, and 20 $(p=0.015) \mathrm{g} \mathrm{N} \mathrm{m}^{-2}$ year $^{-1}$ under the $12-\mathrm{N}$ frequency. Additionally, nos $Z$ gene numbers under the $12-\mathrm{N}$ frequency were significantly higher than those under the 2-N frequency ( $p=$ $0.0189)$. The nos $Z$ gene abundances were found to have negative correlations with $\mathrm{P}$ concentrations $(R=-0.651, p=0.005)$ under the 2-N frequency and negatively correlated with $\mathrm{NH}_{4}-$

\section{Discussion}

4.1 Soil available $\mathrm{N}$ and $\mathrm{pH}$ are main controlling factors for the NFG abundances

Soil available $\mathrm{N}$ is a crucial ecological factor for growth, metabolism, and community of microorganisms (Cheever et al. 2013; Ramirez et al. 2012), especially in N-limited soils. The $\mathrm{N}$ limiting can be mitigated by fertilization and deposition (Levy-Booth et al. 2014), supplying nutrient and energy for basic metabolism and growth of microorganisms, which contributed to the significant increases of nifH $(2 \mathrm{~N}$ and $12 \mathrm{~N})$, AOA-amoA $(12 \mathrm{~N})$, AOB-amoA $(2 \mathrm{~N}$ and $12 \mathrm{~N}) \operatorname{mirS}(2 \mathrm{~N}$ and $12 \mathrm{~N})$, and $\operatorname{nos} Z(12 \mathrm{~N})$ gene abundances at the low $\mathrm{N}$ 
Fig. 3 Gene copy numbers of functional genes involved in major steps of the nitrogen cycle (nifH, chiA, AOA-amoA, AOBamoA, narG, nirK, nirS, and nos $Z$ ) under different $\mathrm{N}$ addition rates and frequencies. Significant polynomial quadratic regression coefficients of the best-fitting models are reported as $* p<0.05$; $p<0.01^{* *} ; p<0.001 * * * . N S$ indicates non-significant $(p>0.05)$

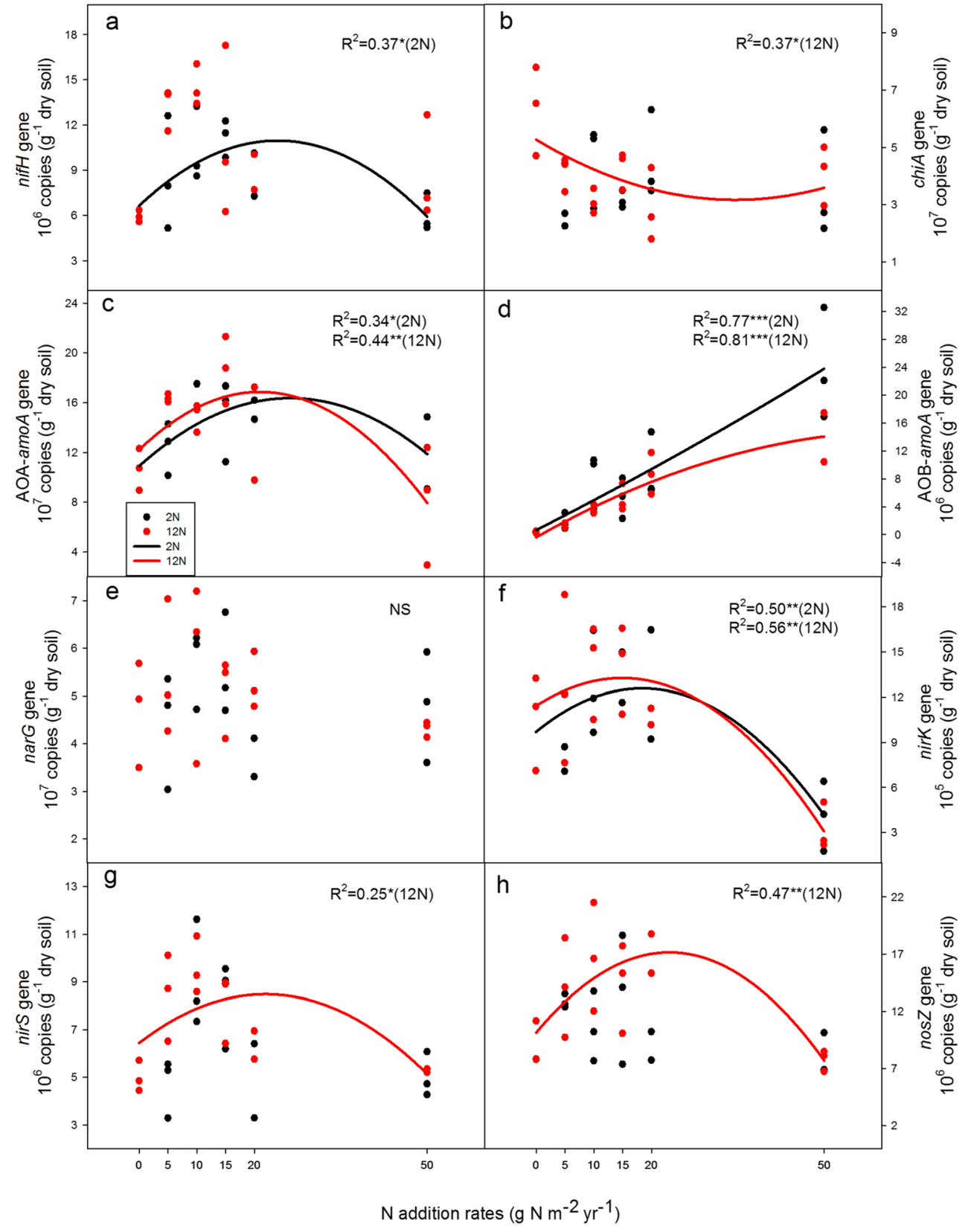

addition rates. The gene abundances of nifH, AOA-amoA, nirS, and nos $Z$ largely peaked at relative low $\mathrm{N}$ rate 10 $15 \mathrm{~g} \mathrm{~N} \mathrm{~m}^{-2}$ year $^{-1}$ under the two frequencies. Previous research also found that the improved available $\mathrm{N}$ stimulated the abundances of NFG genes (Chon et al. 2009; Erguder et al. 2009; Hai et al. 2009; Hayden et al. 2010; Hofferle et al. 2010; Kowalchuk and Stephen 2001; Okano et al. 2004; Zhang et al. 2013). Oxidation of ammonia to nitrite catalyzed by ammonia-oxidizing bacteria and archaea could be an important pathway of nitrite (Huang et al. 2014), which might reduce the dependence of nitrate reduction on narG gene and resulted in no abundance changes.
However, the microbes are not always limited by $\mathrm{N}$, the continual increase of $\mathrm{N}$ addition will cause negative effects (Treseder 2008), including soil acidification (Shen et al. 2008), toxic osmotic potential of soil solution (Broadbent 1965), and altered nutrient status imbalance (Vitousek 1997; Waldrop and Zak 2006), on soil microbial gene abundances. The long-term and high amount $\mathrm{N}$ addition definitely induced the soil acidification (Enwall et al. 2005; Kowalchuk and Stephen 2001; Shen et al. 2008), which resulted in the significant decrease of nifH, AOA-amoA, nirS, and nosZ gene abundances at the highest $\mathrm{N}$ addition rate, compared with their peak abundances which were improved by the $\mathrm{N}$ addition 
Fig. 4 Relationships between $A O A$-amoA, AOB-amoA, and nirK gene abundance, with ammonium $\left(\mathrm{NH}_{4}{ }^{+}-\mathrm{N}\right)$ and nitrate $\left(\mathrm{NO}_{3}{ }^{-} \mathrm{N}\right)$ concentration of $2 \mathrm{~N}(\mathrm{~N}$ addition 2 times/year) and $12 \mathrm{~N}$ ( $\mathrm{N}$ addition 12 times/year) frequencies. The inorganic $\mathrm{N}$ concentration is log natural transformed. No regression is fitted for relationship between AOA-amoA abundance and inorganic $\mathrm{N}$ (ammonium and nitrate, respectively) concentration in 2-N frequency. Significant linear regressions are best fitted for the relationships between AOB-amoA abundances and ammonium concentration $(2 \mathrm{~N}$ and $12 \mathrm{~N})$ and nitrate concentration $(2 \mathrm{~N})$. Significant quadratic regressions are best fitted for all the other relationships. Coefficients of the best-fitting models are reported as ${ }^{*} p<0.05 ; *{ }^{*} p<0.01$; $* * * p<0.001$

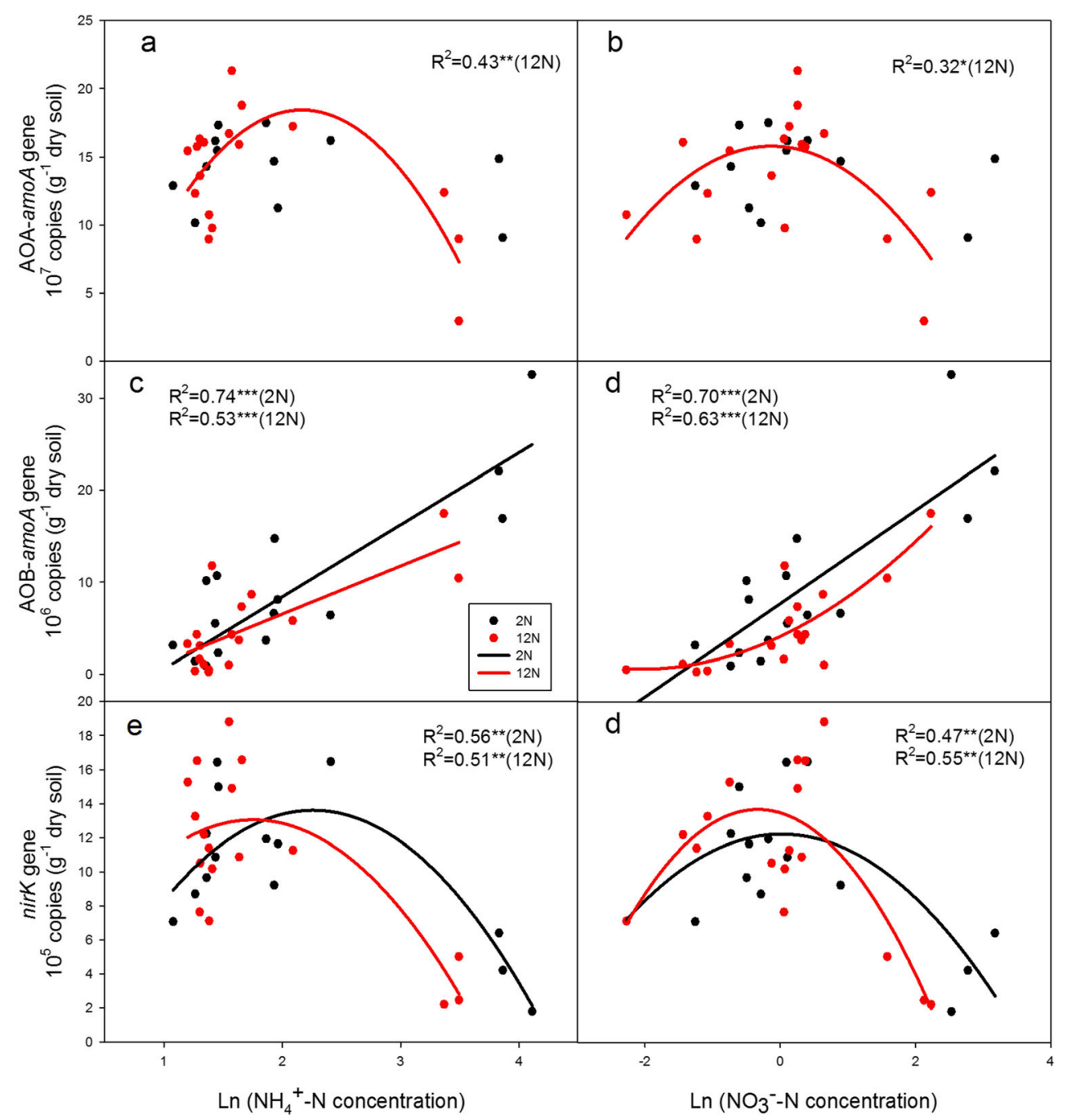

under the two frequencies. Soil $\mathrm{pH}$ appeared to be an important factor influencing NFG abundances and microbial functions (Lindsay et al. 2010; Wakelin et al. 2009; Wallenstein et al. 2006). Microorganisms prefer certain $\mathrm{pH}$ levels in the substance or environment in which they grow (Rousk et al. 2010). The low pH may also cause strong absorption of molybdenum, which is a regulator of the $\mathrm{N}$ fixers (Jarrell and Dawson 1978). Zhang et al. (2013) found that soil pH contributed to the decrease of chiA gene abundance. The nirK gene abundances were significant decreased at rate $50 \mathrm{~g} \mathrm{~N} \mathrm{~m}^{-2}$ year $^{-1}$ under the two $\mathrm{N}$ addition frequencies compared with abundances in the control plots, which can be explained by the suppression of soil $\mathrm{pH}$ (Lindsay et al. 2010); positive relationship with soil $\mathrm{pH}$ was only found under the $12-\mathrm{N}$ frequency. For AOA-amoA gene, compared to abundances in the control plots, there was a slight reduction $(p=0.064)$ at rate $50 \mathrm{~g} \mathrm{~N} \mathrm{~m}^{-2}$ year $^{-1}$ of the $12-\mathrm{N}$ frequency with $\mathrm{pH} 5.5$. The generally accepted explanation is the exponential reduction in ammonium availability with decreasing
pH (Frijlink et al. 1992), and the low soil pH caused by the $\mathrm{N}$ addition was a more important factor than the added $\mathrm{N}$ itself as substrates supply (He et al. 2007).

The hump-shaped relationships between AOA-amoA gene abundances and nitrate concentrations, and between nirK gene abundances and inorganic $\mathrm{N}$ concentrations, reveal that there should be optimum inorganic $\mathrm{N}$ concentrations for their livings. Additionally, accumulated N (ammonia, nitrate, and nitrite) at relatively high $\mathrm{N}$ addition rates resulted in high salt concentrations and toxicity which also inhibited the abundance of nifH, chiA, AOA-amo A, nirK, nirS, and nosZ genes (Hayden et al. 2010; Lindsay et al. 2010; Töwe et al. 2010; Wallenstein et al. 2006). The gene abundances of nifH (12 N) and nosZ $(2 \mathrm{~N})$ were negatively correlated with $\mathrm{P}$ concentrations, and AOB-amoA $(2 \mathrm{~N})$ were negatively correlated with $\mathrm{C} / \mathrm{N}$ and $\mathrm{C} / \mathrm{P}$ ratios indicating that the enrichment of $\mathrm{N}$ resource in the soil may have shifted microbes from being limited by the $\mathrm{N}$ resource to the $\mathrm{C}$ and $\mathrm{P}$ limitation (Zhang et al. 2013), which were also regulators of gene abundances. 
Small changes in the $\mathrm{N}$ cycling are hypothesized to induce disproportionately large shifts in the dynamic of ecosystems (Yergeau et al. 2007). The increase of gene abundances would improve soil $\mathrm{N}$ transformation; in contrast, the decrease would suppress the $\mathrm{N}$ transformation. Therefore, it is of central importance to elucidate the extent to which the gene abundance would be improved or suppressed by the $\mathrm{N}$ addition.

4.2 Roles of microbial functional genes with high sensitivity in $\mathrm{N}$ deposition

All the $\mathrm{N}$ addition rates reduced chiA gene abundances by the same extent even at the lowest $\mathrm{N}$ addition rates, and we suggested that a very small $\mathrm{N}$ dose $\left(0-5 \mathrm{~g} \mathrm{~N} \mathrm{~m}^{-2}\right.$ year $\left.^{-1}\right)$ can greatly influence chiA gene abundances, and then the lower $\mathrm{N}$ addition levels ranged and related abiotic factors should be studied exclusively to locate the point at which the chiA gene abundance would begin to decrease, which is necessary to prove the contribution of chiA group in decomposition processes. The AOB-amoA gene abundance presented sharp growth with increasing $\mathrm{N}$ addition rates and inorganic $\mathrm{N}$ concentrations, including absolute growth at lowest $\mathrm{N}$ rate, indicating the sensitive response to the $\mathrm{N}$ addition and a stimulating effect of $\mathrm{N}$ addition on AOB-amoA population size (Di et al. 2010; Hallin et al. 2009; Weng et al. 2013; Zhang et al. 2013). In consideration of high sensitivity of chiA and AOBamo $A$ gene abundances to the $\mathrm{N}$ addition, and their functions in regualting $\mathrm{N}$ cycling, $\mathrm{N}$ mineralization and nitrification processes can certainly be perturbed by the $\mathrm{N}$ deposition even at a small dose. Therefore, chiA and AOB-amoA gene can be used as sentinel organisms to project and monitor future $\mathrm{N}$ deposition by using ambient gradients of $\mathrm{N}$ addition (Stevens et al. 2004; Zhang et al. 2014b).

\subsection{Frequencies of $\mathrm{N}$ addition prompted distinct responsive patterns of the NFG abundances}

Abundances of nifH, AOB-amoA, nirS, and nos $Z$ genes were diverged by the two $\mathrm{N}$ addition frequencies, indicating that large and infrequent $\mathrm{N}$ fertilization would likely cause biased assessment of the effects on NFGs as well as on N transformation processes, compared with small and frequent $\mathrm{N}$ deposition. There should be mechanisms responsible for these differences within the soil-microbe system. The $\mathrm{N}$ addition frequencies lead to distinct accumulated mineral $\mathrm{N}$ concentrations and the associated soil acidification, which principally regulated the responsive patterns of different gene abundances. At the same site, the low $\mathrm{N}$ addition frequency may result in a weaker potential than the high $\mathrm{N}$ addition frequency to emit gas (in the form of ammonia) (Zhang et al. 2013), and then more mineral $\mathrm{N}$ was accumulated under the 2-N frequency; consequently, the toxicity solution and acidification of soil inhibited the gene abundances of nifH, nirS, and nos $Z$ under the 2-N frequency. In contrast, the 2-N frequency induced significantly higher AOB-amoA gene abundances compared with the $12-\mathrm{N}$ frequency, mainly due to higher $\mathrm{N}$ availability under the 2-N frequency. According to the negative correlation between $\mathrm{N}$ availability and soil acidification, we suggested that in the $\mathrm{pH}$ range 5.5-7.5 in this study, the promoting effect of $\mathrm{N}$ availability outstripped the inhibiting effect of soil acidification, and then $\mathrm{N}$ availability was the main driver for AOB- amoA gene abundance rather than the soil acidification.

An additional reason for the difference was that, when the same total $\mathrm{N}$ loading in a singular pulse rather than frequent deposition, the toxicity of mineral $\mathrm{N}$ and soil acidification tend to be aggravating, and then the peak effect of infrequent $\mathrm{N}$ addition prompted distinct responsive patterns of the NFG abundances. Then, the accumulative toxicity and acidification resulted in the lower abundances of nifH, nirS, and nos Z under the 2-N frequency, and peak enriched available $\mathrm{N}$ resulted in higher abundances of AOB-amoA gene under the 2-N frequency, respectively. Boyle-Yarwood et al. (2008) found that the plant species were linked to the differences in AOA-amoA and AOB-amoA community. The rapid plant species loss under the 2-N frequency (Zhang et al. 2014b) might lead to different rhizospheric conditions, such as soil organic C, which also influence response patterns of NFG abundances. The plant-microbe mechanism involved in this experiment should further studied, to reveal how the plant species changes regulate the abundance and function of NFGs.

Overall, according to the abundance response of NFGs, the large and infrequent fertilization in previous $\mathrm{N}$ enrichment experiments might potentially underestimate the effects of $\mathrm{N}$ deposition on $\mathrm{N}$ fixation and denitrification processes and overestimate the effects of $\mathrm{N}$ deposition on nitrification process. We should not simply simulate $\mathrm{N}$ deposition by large and infrequent $\mathrm{N}$ addition or confound their influences.

\section{Conclusions}

Our results indicated that $\mathrm{N}$ addition rates largely altered almost all the gene abundances measured in this study and consequently altered the driven processes. The chiA and AOBamo $A$ groups with great sensitive responses to rates of $\mathrm{N}$ addition can be used as indicators for future aerial $\mathrm{N}$ deposition. It is crucial to track the rate at which the gene abundances having reverse changes, to reveal the changes of processes of $\mathrm{N}$ cycling. The large and infrequent $\mathrm{N}$ addition caused diverged responsive patterns of nifH, nirS, nosZ, and AOBamo $A$ gene abundances, compared with small and frequent $\mathrm{N}$ addition; the corresponding functions and processes were also deduced to be influenced. Thus, the continuous, long-term field experiments with independently manipulated rates and 
frequencies are required to accurately elucidate the influences of $\mathrm{N}$ deposition on $\mathrm{N}$ cycling processes.

Acknowledgments We thank Jianjun Chen, Jian Xu, Shuchao Wang, and Dongsheng Miao, for the assistance in sampling and sample measurement. This work was supported by the Strategic Priority Research Program of the Chinese Academy of Sciences (XDB15010401 and XDB15010403) and the National Natural Science Foundation of China (31170433 and 31307337).

\section{References}

Attard E, Recous S, Chabbi A, De Berranger C, Guillaumaud N, Labreuche J, Philippot L, Schmid B, Le Roux X (2011) Soil environmental conditions rather than denitrifier abundance and diversity drive potential denitrification after changes in land uses. Glob Chang Biol 17:1975-1989

Bai YF, Wu JG, Clark CM, Naeem S, Pan QM, Huang JH, Zhang LX, Han XG (2010) Tradeoffs and thresholds in the effects of nitrogen addition on biodiversity and ecosystem functioning: evidence from inner Mongolia Grasslands. Glob Chang Biol 16:358-372

Barton L, Wan GGY, Buck RP, Colmer TD (2008) Does N fertiliser regime influence $\mathrm{N}$ leaching and quality of different-aged turfgrass (Pennisetum clandestinum) stands? Plant Soil 316:81-96

Bilbrough CJ, Caldwell M (1997) Exploitation of springtime ephemeral $\mathrm{N}$ pulses by six great basin plant species. Ecology 78:231-243

Boyle-Yarwood SA, Bottomley PJ, Myrold DD (2008) Community composition of ammonia-oxidizing bacteria and archaea in soils under stands of red alder and Douglas fir in Oregon. Environ Microbiol 10: 2956-2965

Braker G, Gesefeldt A, Witzel K-P (1998) Development of PCR primer systems for amplification of nitrite reductase genes (nirK and nirS) to detect denitrifying bacteria in environmental samples. Appl Environ Microbiol 64:3769-3775

Broadbent FE (1965) Effects of fertilizer nitrogen on the release of soil nitrogen. Soil Sci Soc Am J 29:692-696

Cheever BM, Webster JR, Bilger EE, Thomas SA (2013) The relative importance of exogenous and substrate-derived nitrogen for microbial growth during leaf decomposition. Ecology 94:1614-1625

Cheng XL, Luo YQ, Su B, Verburg PSJ, Hui DF, Obrist D, Arnone JA, Johnson DW, Evans RD (2009) Responses of net ecosystem CO2 exchange to nitrogen fertilization in experimentally manipulated grassland ecosystems. Agr Forest Meteorol 149:1956-1963

Chon K, Chang J-S, Lee E, Lee J, Ryu J, Cho J (2009) Abundance of denitrifying genes coding for nitrate (narG), nitrite (nirS), and nitrous oxide (nosZ) reductases in estuarine versus wastewater effluent-fed constructed wetlands. Ecol Eng 37:64-69

Colloff MJ, Wakelin SA, Gomez D, Rogers SL (2008) Detection of nitrogen cycle genes in soils for measuring the effects of changes in land use and management. Soil Biol Biochem 40:1637-1645

Delorme S, Philippot L, Edel-Hermann V, Deulvot C, Mougel C, Lemanceau P (2003) Comparative genetic diversity of the narG, nosZ, and 16S rRNA genes in fluorescent pseudomonads. Appl Environ Microbiol 69:1004-1012

Di HJ, Cameron KC, Shen JP, Winefield CS, O'Callaghan M, Bowatte S, He JZ (2010) Ammonia-oxidizing bacteria and archaea grow under contrasting soil nitrogen conditions. FEMS Microbiol Rev 72:386394

Enwall K, Philippot L, Hallin S (2005) Activity and composition of the denitrifying bacterial community respond differently to long-term fertilization. Appl Environ Microbiol 71:8335-8343
Erguder TH, Boon N, Wittebolle L, Marzorati M, Verstraete W (2009) Environmental factors shaping the ecological niches of ammoniaoxidizing archaea. FEMS Microbiol Rev 33:855-869

Francis CA, Roberts KJ, Beman JM, Santoro AE, Oakley BB (2005) Ubiquity and diversity of ammonia-oxidizing archaea in water columns and sediments of the ocean. Proc Natl Acad Sci U S A 102: $14683-14688$

Frijlink MJ, Abee T, Laanbroek HJ, De Boer W, Konings WN (1992) The bioenergetics of ammonia and hydroxylamine oxidation in Nitrosomonas europaea at acid and alkaline pH. Arch Microbiol 157:194-199

Galloway JN, Dedterner FJ, Capone DG, Boyer EW, Howarth RW, Seitzinger SP, Asner GP, Cleveland CC, Green PA, Holland EA, Karl DM, Micheals AF, Porter JH, Townsend AR, Vöosmarty CJ (2004) Nitrogen cycles: past, present, and future. Biochem 70:153-226

Galloway JN, Leach AM, Bleeker A, Erisman JW (2013) A chronology of human understanding of the nitrogen cycle. Proc R Soc Lond B: 368

Hai B, Diallo NH, Sall S, Haesler F, Schauss K, Bonzi M, Assigbetse K, Chotte JL, Munch JC, Schloter M (2009) Quantification of key genes steering the microbial nitrogen cycle in the rhizosphere of sorghum cultivars in tropical agroecosystems. Appl Environ Microbiol 75:4993-5000

Hallin S, Jones CM, Schloter M, Philippot L (2009) Relationship between $\mathrm{N}$-cycling communities and ecosystem functioning in a 50-year-old fertilization experiment. ISME J 3:597-605

Hayden HL, Drake J, Imhof M, Oxley APA, Norng S, Mele PM (2010) The abundance of nitrogen cycle genes amoA and nifH depends on land-uses and soil types in South-Eastern Australia. Soil Biol Biochem 42:1774-1783

He JZ, Shen JP, Zhang LM, Zhu YG, Zheng YM, Xu MG, Di HJ (2007) Quantitative analyses of the abundance and composition of ammonia-oxidizing bacteria and ammonia-oxidizing archaea of a Chinese upland red soil under long-term fertilization practices. Environ Microbiol 9:2364-2374

Hofferle S, Nicol GW, Pal L, Hacin J, Prosser JI, Mandic-Mulec I (2010) Ammonium supply rate influences archaeal and bacterial ammonia oxidizers in a wetland soil vertical profile. FEMS Microbiol Rev 74: 302-315

Huang T, Gao B, Hu XK, Lu X, Well R, Christie P, Bakken LR, Ju XT (2014) Ammonia-oxidation as an engine to generate nitrous oxide in an intensively managed calcareous Fluvo-aquic soil. Sci Rep 4:3950

Jarrell WM, Dawson MD (1978) Sorption and availability of molybdenum in soils of western oregon. Soil Sci Soc Am J 42:412-415

Jia YL, Yu GR, He NP, Zhan XY, Fang HJ, Sheng WP, Zuo Y, Zhang DY, Wang QF (2014) Spatial and decadal variations in inorganic nitrogen wet deposition in China induced by human activity. Sci Rep 4: 3763

Jia ZJ, Conrad R (2009) Bacteria rather than Archaea dominate microbial ammonia oxidation in an agricultural soil. Environ Microbiol 11: $1658-1671$

Jung J, Yeom J, Kim J, Han J, Lim HS, Park H, Hyun S, Park W (2011) Change in gene abundance in the nitrogen biogeochemical cycle with temperature and nitrogen addition in Antarctic soils. Res Microbiol 162:1018-1026

Kandeler E, Deiglmayr K, Tscherko D, Bru D, Philippot L (2006) Abundance of narG, nirS, nirK, and nosZ genes of denitrifying bacteria during primary successions of a glacier foreland. Appl Environ Microbiol 72:5957-5962

Kandeler E, Brune T, Enowashu E, Dorr N, Guggenberger G, Lamersdorf N, Philippot L (2009) Response of total and nitrate-dissimilating bacteria to reduced $\mathrm{N}$ deposition in a spruce forest soil profile. FEMS Microbiol Ecol 67:444-454

Kloos K, Mergel A, Rösch C, Bothe H (2001) Denitrification within the genus Azospirillum and other associative bacteria. Aust J Plant Physiol 28:991-998 
Kowalchuk GA, Stephen JR (2001) Ammonia-oxidizing bacteria a model for molecular microbial ecology. Annu Rev Microbiol 55:485-529

Leininger S, Urich T, Schloter M, Schwark L, Qi J, Nicol GW, Prosser JI, Schuster SC, Schleper C (2006) Archaea predominate among ammonia-oxidizing prokaryotes in soils. Nature 442:806-809

Levy-Booth DJ, Prescott CE, Grayston SJ (2014) Microbial functional genes involved in nitrogen fixation, nitrification and denitrification in forest ecosystems. Soil Biol Biochem 75:11-25

Lindsay EA, Colloff MJ, Gibb NL, Wakelin SA (2010) The abundance of microbial functional genes in grassy woodlands is influenced more by soil nutrient enrichment than by recent weed invasion or livestock exclusion. Appl Environ Microbiol 76:5547-5555

Michotey V, Méjean V, Patricia B (2000) Comparison of methods for quantification of cytochrome cd1-Denitrifying bacteria in environmental marine samples. Appl Environ Microbiol 66:1564-1571

Nelson DW, Sommers LE (1982) Dry combustion method using medium temperature resistance furnace. In: Page AL, Miller RH, Keeney D (eds) Methods of soil analysis. Part 2. Chemical and Microbial Properties. ASA and SSSA, Madison

Ochoa-Hueso R, Maestre FT, de Los RA, Valea S, Theobald MR, Vivanco MG, Manrique E, Bowker MA (2013) Nitrogen deposition alters nitrogen cycling and reduces soil carbon content in lowproductivity semiarid Mediterranean ecosystems. Environ Pollut 179:185-193

Okano Y, Hristova KR, Leutenegger CM, Jackson LE, Denison RF, Gebreyesus B, Lebauer D, Scow KM (2004) Application of realtime PCR to study effects of ammonium on population size of ammonia-oxidizing bacteria in soil. Appl Environ Microbiol 70: $1008-1016$

Petersen DG, Blazewicz SJ, Firestone M, Herman DJ, Turetsky M, Waldrop M (2012) Abundance of microbial genes associated with nitrogen cycling as indices of biogeochemical process rates across a vegetation gradient in Alaska. Environ Microbiol 14:993-1008

Rösch C, Mergel A, Bothe H (2002) Biodiversity of denitrifying and dinitrogen-fixing bacteria in an acid forest soil. Appl Environ Microbiol 68:3818-3829

Ramirez KS, Craine JM, Fierer N (2012) Consistent effects of nitrogen amendments on soil microbial communities and processes across biomes. Glob Chang Biol 18:1918-1927

Rotthauwe JH, Witzel KP, Liesack W (1997) The ammonia monooxygenase structural gene amoA as a functional marker molecular fine scale analysis of natural ammoniaoxidizing populations. Appl Environ Microbiol 63:4704-4712

Rousk J, Baath E, Brookes PC, Lauber CL, Lozupone C, Caporaso JG, Knight R, Fierer N (2010) Soil bacterial and fungal communities across a $\mathrm{pH}$ gradient in an arable soil. ISME J 4:1340-1351

Sala OE, Chapin FSR, Armesto JJ, Berlow E, Bloomfield J, Dirzo R, Huber-Sanwald E, Huenneke LF, Jackson RB, Kinzig A, Leemans R, Lodge DM, Mooney HA, Oesterheld M, Poff NL, Sykes MT, Walker BH, Walker M, Wall DH (2000) Global biodiversity scenarios for the year 2100. Science 287:1770-1774

Shen JP, Zhang LM, Zhu YG, Zhang JB, He JZ (2008) Abundance and composition of ammonia-oxidizing bacteria and ammonia-oxidizing archaea communities of an alkaline sandy loam. Environ Microbiol 10:1601-1611

Shen JP, Xu ZH, He JZ (2014) Frontiers in the microbial processes of ammonia oxidation in soils and sediments. J Soils Sediments 14: 1023-1029

Stevens CJ, Dise NB, Mountford JO, Gowing DJ (2004) Impact of nitrogen deposition on the species richness of grasslands. Science 303: 1876-1879
Stevens CJ, Dupre C, Dorland E, Gaudnik C, Gowing DJ, Bleeker A, Diekmann M, Alard D, Bobbink R, Fowler D, Corcket E, Mountford JO, Vandvik V, Aarrestad PA, Muller S, Dise NB (2010) Nitrogen deposition threatens species richness of grasslands across Europe. Environ Pollut 158:2940-2945

Töwe S, Albert A, Kleineidam K, Brankatschk R, Dumig A, Welzl G, Munch JC, Zeyer J, Schloter M (2010) Abundance of microbes involved in nitrogen transformation in the rhizosphere of Leucanthemopsis alpina (L.) Heywood grown in soils from different sites of the Damma glacier forefield. Microb Ecol 60:762-770

Throbäck IN, Enwall K, Jarvis A, Hallin S (2004) Reassessing PCR primers targeting nirS, nirK and nosZ genes for community surveys of denitrifying bacteria with DGGE. FEMS Microbiol Rev 49:401417

Treseder KK (2008) Nitrogen additions and microbial biomass: a metaanalysis of ecosystem studies. Ecol Lett 11:1111-1120

Veresoglou SD, Chen BD, Rillig MC (2012) Arbuscular mycorrhiza and soil nitrogen cycling. Soil Biol Biochem 46:53-62

Vitousek PM, Howarth RW (1991) Nitrogen limitation on land and in the sea: how can it occur? Biogeochemistry 13:87-115

Vitousek PM (1997) Human domination of earth's ecosystems. Science 277:494-499

Wakelin SA, Gregg AL, Simpson RJ, Li GD, Riley IT, McKay AC (2009) Pasture management clearly affects soil microbial community structure and N-cycling bacteria. Pedobiologia 52:237-251

Waldrop MP, Zak DR (2006) Response of oxidative enzyme activities to nitrogen deposition affects Soil concentrations of dissolved organic carbon. Ecosystems 9:921-933

Wallenstein MD, Myrold DD, Firestone M, Voytek M (2006) Environmetal controls on denitrifying cimmunities and denitrification rates insights from molecular methods. Ecol Appl 16:21432152

Wang YZ, Xu ZH, Zhou QX (2014) Impact of fire on soil gross nitrogen transformations in forest ecosystems. J Soils Sediments 14:1030 1040

Weng BS, Xie XJ, Yang JJ, Liu JC, Lu HL, Yan CL (2013) Research on the nitrogen cycle in rhizosphere of Kandelia obovata under ammonium and nitrate addition. Mar Pollut Bull 76:227-240

Xiao X, Yin X, Lin J, Sun L, You Z, Wang P, Wang F (2005) Chitinase genes in lake sediments of Ardley Island, Antarctica. Appl Environ Microbiol 71:7904-7909

$\mathrm{Xu} \mathrm{ZH}$, Chen CR (2006) Fingerprinting global climate change and forest management within rhizosphere carbon and nutrient cycling processes. Environ Sci Pollut Res 13:293-298

Xu ZH, Chen CR, He JZ, Liu JX (2009) Trends and challenges in soil research 2009: linking global climate change to local long-term forest productivity. J Soils Sediments 9:83-88

Yergeau E, Kang S, He Z, Zhou J, Kowalchuk GA (2007) Functional microarray analysis of nitrogen and carbon cycling genes across an Antarctic latitudinal transect. ISME J 1:163-179

Zhang XM, Liu W, Schloter M, Zhang GM, Chen QS, Huang JH, Li LH, Elser JJ, Han XG (2013) Response of the abundance of key soil microbial nitrogen-cycling genes to multi-factorial global changes. PLoS One 8:e76500

Zhang YH, Han X, He NP, Long M, Huang JH, Zhang GM, Wang QB, Han XG (2014a) Increase in ammonia volatilization from soil in response to $\mathrm{N}$ deposition in Inner Mongolia grasslands. Atmos Environ 84:156-162

Zhang YH, Lü XT, Isbell F, Stevens C, Han X, He NP, Zhang GM, Yu Q, Huang JH, Han XG (2014b) Rapid plant species loss at high rates and at low frequency of $\mathrm{N}$ addition in temperate steppe. Glob Chang Biol 20:3520-3529 